horizontal antennæ being thus utilised. The observations were not sufficiently numerous to justify definite conclusions being drawn, but so far as they went they tended to support Mr. Marconi's results as to the southerly origin of these disturbances.

The aërials of many stations are, of course, to some extent directive, and this may account for the comparative immunity of one station from atmospherics while another in its vicinity is more disturbed by them, although both might be affected equally by local thunderstorms.

Wilfred Hall.

H. Morris-Ayrey.

9 Priors Terrace, Tynemouth,

Northumberland, January 12 .

\section{A Recently Discovered Stone Circle, near Matlock, Derbyshire.}

ON the summit of "Bilberry Knoll," in the district of Matlock, latitude $53^{\circ} 7^{\prime} \mathrm{I}^{\frac{1}{2}}{ }^{\prime \prime}$, and longitude $\mathrm{I}^{\circ} 32^{\prime} \mathrm{I}^{\prime \prime}$ W., there are remains of what I believe to have been an important station in prehistoric times, dedicated to the sun-worship cult.

The highest point of the hill is crowned by a mound, obviously artificial, built up of large boulders and earth, and, although much disturbed, many of the stones occupy positions in which they were originally placed. Some of them appear to form part of the circumference of a circle with thirty-six bays, or divisions, of $\mathrm{I} 44 \mathrm{ft}$. diameter. Near the centre there are two chambers, one in horse-shoe form, and the axis through these chambers is in line with the "Nine Ladies," a well-known circle, on Stanton Moor.

The range of hills (of which Bilberry Knoll forms the highest point, $928 \mathrm{ft}$. above O.D.) occupies a very strong natural position, and the summit was apparently further protected by ramparts, remains of which may be seen about 200 yards south of the circle mound.

The circle commands an extensive view in every direction, and there are in sight more than thirty positions which bear distinctive names.

To discover the significance of some of these positions I have taken observations of the sunset on those days usually regarded as sacred in the "Druidical," or sun-worship cult, more particularly of the May Eve and June Solstice festivals. But sunsets down to the horizon are rare, and I had no data by which to determine the true date of May Eve. I ultimately decided on May II as being consonant with May Eve (old style), and this year, on that date, the full disc of the sun rested upon a distant horizon (altitude Io'), exactly over the intersection of intervening hills, on an alignment $\mathrm{N} .5^{\circ} \mathrm{oo}^{\prime} \mathrm{W}$.

At the June solstice the results were more decisive, the sunset being almost exactly over the "Nine Ladies." This well-known circle lies a little more than five miles away, N. $46^{\circ} 30^{\prime}$ W., and the height of horizon is about $13^{\prime}$. And N. $46^{\circ} \mathrm{oo}^{\prime}$ E., with a similar altitude, stands "Blakelow Hill"; this hill would thus indicate the rising sun, and, conjointly with the "Nine Ladies," provides irrefutable evidence of purpose. For, whereas "Blakelow Hill" is a distinctive natural feature, the "Nine Ladies" occupies a chosen site, slightly below the highest ground, on a broad plateau. And, whilst it is in sight, and indicates the sunset from "Bilberry Knoll," it is not in sight from a circle only $\mathrm{I}_{\frac{3}{4}}$ miles away on Harthill Moor, nor from "Arbor Low," which is within $5 \frac{1}{2}$ miles, though a difference of very few yards in position, on higher ground, would have placed it in sight of all three. It was therefore clearly established as an adjunct to "Bilberry Knoll."

Comparing these results with data which I have NO. 2307 , VOL. 92$]$ since obtained from Sir Norman Lockyer's valuable work on "Stonehenge," I find the alignment for sunset on May 6 to be about N. $6 \mathrm{I}^{\circ} \mathrm{oo}^{\prime} \mathrm{W}$., but the date actually observed appears to be subject to local variation, the Roman calendar being May 9 (the date of a fair day at Matlock). Making allowance for this, and for variation in obliquity of the ecliptic, it seems probable that this hill intersection would indicate the sunset on the eve of the May year festival.

The alignment for the June solstice I make N. $47^{\circ}$ I5' W., which is so near as practically to confirm my conclusions.

Investigations on the various sites would, I believe, prove that the better-known Derbyshire circles, "Arbor Low," the "Bull Ring" at Dove Holes, and "Wet Withins" on Eyam Moor, were also established with alignments to distinctive features that would indicate the rising and setting sun on these dates.

\section{Spring Mount, Bank Road, Matlock,} JOHN Simpson. January 5 .

\section{Trepanning among Ancient Peoples.}

A NOTE in Nature of October 30, I9I3, p. 273 referring to the late Dr. Lucas Championniere's paper on prehistoric trepanning, which was read at the last annual public meeting of the Five Academies in Paris, contains this observation:-

"It is remarkable that the operation was not practised among highly civilised races like Greeks, Egyptians, Arabs, Hindus, and Chinese. . . ."

But the subjoined quotations would seem to militate with the soundness of this expression so far as it concerns the ancient peoples of Greece and India :-

"In surgery his (Hippocrates's) writings are important and interesting, but they do not bear the same character of caution as the treatises on medicine; for instance, in the essay ' On the Injuries of the Head,' he advocates the operation of 'trephining' more strongly and in wider classes of cases than would be warranted by the experience of later times" ("Encyclopædia Britannica," I9Io, vol. xiii., p. 5I8).

"The next most elaborate chapter (of the Hippocratic collection) is that on wounds and injuries of the head. . . . Trephining was the measure most commonly resorted to, even where there was no compression" (ibid., vol. xxvi., p. 125).

"Jivaka (afterwards termed the King of the Physicians) had learnt the whole art of healing with the exception of the operation of skull-opening. Now a man who was afflicted by a cerebral malady came to Atreya (Jivaka's master) and asked him to treat him. Atreya replied that the man must dig a pit that day and provide it with dung. . . . When Atreya came, he placed the man in the pit, opened his skull, and was about to seize the reptile with his pincers (when Jivaka advised him how to take it away). . . . When all this had been done the man was cured" (E. A. von Schiefner, "Tibetan Tales," trans. Ralston, I906, p. 98). The same book, p. roo, relates how Jivaka cured a man whose head itched greatly by drawing out of his skull a centipede through the same operation. In the "Lives of Jivaka and Amrapäli (his mother)," translated into Chinese in the second century A.D., he is said to have used a golden knife in skull-opening.

"Les Saniassis sont enterrés jusqu'au col; un Religieux du même ordre casse des cocos sur la tête du mort jusqu'à ce qu'elle soit brisée; ensuite on la couvre de terre. On ignore aujourd'hui le motif de cette pratique singulière, à moins que ce ne soit pas pour faciliter à leur âme le moyen de sortir par une ouverture plus honnête que la bouche, les oreilles et 